\title{
The Impact of Learning Strategy of Problem Solving and Discovery towards Learning Outcomes Reviewed from Students Learning Motivation
}

\author{
Budi Murtiyasa, Intan Indraswari Al Karomah* \\ Department of Mathematics Education, Faculty of Teacher Training and Education, Universitas Muhammadiyah Surakarta, Indonesia
}

Received May 30, 2020; Revised July 9, 2020; Accepted August 10, 2020

\begin{abstract}
Cite This Paper in the following Citation Styles
(a): [1] Budi Murtiyasa, Intan Indraswari Al Karomah, "The Impact of Learning Strategy of Problem Solving and Discovery towards Learning Outcomes Reviewed from Students Learning Motivation, "Universal Journal of Educational Research, Vol. 8, No. 9, pp. 4105-4112, 2020. DOI: 10.13189/ujer.2020.080936.
\end{abstract}

(b): Budi Murtiyasa, Intan Indraswari Al Karomah (2020). The Impact of Learning Strategy of Problem Solving and Discovery towards Learning Outcomes Reviewed from Students Learning Motivation. Universal Journal of Educational Research, 8(9), 4105-4112. DOI: 10.13189/ujer.2020.080936.

Copyright $\mathrm{C} 2020$ by authors, all rights reserved. Authors agree that this article remains permanently open access under the terms of the Creative Commons Attribution License 4.0 International License

\begin{abstract}
The research aims at examining: (1) the impact of Problem Solving Strategy and Discovery Learning Strategy on mathematics learning outcomes, (2) the impact of learning motivation on mathematics learning outcomes, (3) the interaction between learning strategies seen from the learning motivation on mathematics learning outcomes. Type of the research is quantitative with a quasi-experimental design. The population of the research is all of the $7^{\text {th }}$-grade-students at one of state middle school at Surakarta Central Java, Indonesia. A total of 57 students from two different classes were involved in the study, assigned as experimental group and control group. They were selected through cluster random sampling technique. The group which was assigned as the experimental group was instructed through a problem-solving strategy whereas the other group was discovery learning. Data collection techniques used the method of test, questionnaire, and documentation. The technique of data analysis was the two-way analysis of variance. From the analysis, it was concluded that: (1) there are impacts of Problem Solving learning strategy and Discovery Learning on mathematics learning outcomes, (2) there are impacts of student learning motivation on mathematics learning outcomes, (3) there is no interaction between learning strategies and learning motivation on mathematics learning outcomes.
\end{abstract}

Keywords Problem Solving, Discovery Learning, Learning Outcomes, Motivation

\section{Introduction}

Education is a human need that needed in developing human resources. Education is a continuance process by individuals to increase personal potential in social life. Education aids someone in facing the global era and various challenges in the future. In the Indonesian education system, from basic education to tertiary institutions, they study mathematics.

Mathematics is a subject that has an important function in daily life. This is due to mathematics is needed in the development of technology and science. Mathematics can increase the ability to think logically, analytically, systematically, critically, collaboratively, and creatively. Therefore, students need to learn mathematics starting in elementary school. In studying mathematics students are not only memorizing formulas but also knowing mathematical concepts. Student's understanding of mathematical concepts can be applied in contextual problems related to mathematics.

To determine the goals of the student learning process, the teacher analyzed the learning outcomes achieved by students. The teacher employed learning outcomes as an indicator to measure student mastery and understanding of the material provided. Learning outcomes are the values 
obtained from student learning processes following the agreed objectives [15]. Learning outcomes appropriate with the Minimum Mastery Criteria are the expectations of all teachers. However, the fact is mathematics learning outcomes are still not as expected. The results of Programme for International Student Assessment (PISA) 2018 have been released by Organisation for Economic Co-operation and Development (OECD) show that Indonesian students abilities in mathematics achieve an average score 379, with an OECD average score 489 and Indonesia was ranked seventy-fourth out of seventy-nine countries [13].

The factors contributing to the low student learning outcomes are both internal and external. The internal factors are factors that come from students and the external factors are those appearing from the outside. The internal factors include motivation, biological condition, interest, and ability of the students. The external factors are the environment, parents, and teacher. Another factor of students' low learning outcomes is the lack of learning resources and supporting facilities for the learning process.

One of the factors influencing the learning outcomes is motivation. The importance of motivation in learning activities is for encouraging the students to learn. The teacher is expected to motivate the students in learning activities. According to Sardiman, [17] motivation is propulsion that makes a subject active in achieving certain goals. Therefore, motivation is important to encourage students to learn so that they can achieve success in learning.

The learning strategy used by the teacher is also a factor influencing student learning outcomes. Murtiyasa and Hapsari [11] showed that there was an effect of the implementation of Team Assisted Individualization (TAI) and Student Teams Achievement Division (STAD) strategy and also mathematical communication skills on mathematics learning outcomes. Lecturing is a learning strategy that is still widely used. Based on preliminary observations at one of state middle school in Surakarta, Central Java, Indonesia, one of the causes of the low learning outcomes of mathematics is that teachers only use the lecture method in the teaching and learning activities. In the learning process, the teacher only explains that makes the students sleepy and talks to others. The learning process is still centered on the teacher (teacher-centered) so students prefer to respond and only consider the explanation from the teacher. This results in the difficulty of the students to work on the problems with a slightly different concept from those given by the teacher. Therefore, according to Murtiyasa, [10] it is necessary to change the role of the teacher from a lecturer to a facilitator in learning in class. Moreover, in their research, Murtiyasa et al. [12] conclude the importance of planning for mathematics learning to improve students' level of thinking in solving mathematical problems.

The alternative to overcome the problem is to make learning innovations to increase student motivation. This is relevant to the research of Arseven [2] concluding that the application of mathematics teaching models is needed to motivate students in learning. The research of Siswono et al. [20] concluded that students preferred to choose the most effective strategies which could be used for various types of problems. The use of learning strategies appropriate to students' characteristics and needs can improve their motivation to study. The appropriate learning strategies can make learning effective so that the achievement of student learning outcomes can be satisfying.

Analyzing the learning outcome problems, learning strategies must be changed to improve students learning outcomes. Innovative and creative learning strategies can make students more active and motivated in learning. The strategies that can be used for developing student mindsets and reasoning by finding information and concepts, and for solving the problems are Problem Solving Strategy and Discovery Learning Strategy. This case is in line with the research of Tambunan [24] concluding that Problem Solving Strategy way more effective than the Scientific Approach to improve student abilities in communication, creativity, problem-solving, and mathematical reasoning. Besides, the research of Herdiana [5] stated that the application of discovery learning strategies can improve the ability of the students with moderate ability to solve problems. Problem Solving Strategy is learning of solving problems that can lead students to contextual problems so that it can increase students' motivation. Problem Solving is a learning strategy that consists of stages of showing problems to students systematically, and afterward, the students will try to solve the problems and are expected to communicate the analysis of the results.

According to Prasetya et al., [14] the steps of Problem Solving strategy are as follows (1) Identifying Problem, (2) Defining Goals, (3) Exploring the Solutions, (4) Implementing the Strategy, (5) Examining and Evaluating the Impact. In learning mathematics, using of problem-solving strategy can affect students learning outcomes. This corresponds to the research of Sappaile \& Djam'an [16] concluding that mathematics learning outcomes delivered using the Problem-Solving strategy is better than the lecture method. On the other hand, the research of Zulyadaini [29] concluded that students' mathematical solving abilities using problem-solving strategies creatively are higher than those taught using Direct Based Learning. Furthermore, the research of Suastika [21] concluded that development results of using the Problem-Solving learning model openly can develop students' creativity in fulfilling valid, practical, and effective criteria.

Another alternative is using the Discovery Learning Strategy, a learning strategy persuading students to develop their mindsets to find a concept or theory. According to Syah [23], the stages of Discovery Learning strategy are (1) Stimulation, (2) Problem Statement, (3) Data Collection, (4) 
Data Processing, (5) Verification, and (6) Generalization. Problem-solving strategy by finding a concept may improve students learning outcomes. This is in line with the research of Martaida et al. [8] It concludes that Discovery Learning strategy is better than conventional learning based on cognitive abilities and critical thinking abilities of students. Moreover, the research of In'am \& Hajar [7] concluded that the application of the Discovery Learning and Scientific Approach can improve more innovative teacher activities as seen in the well-prepared teachers in the teaching and learning activities to achieve the learning goals. Furthermore, the research of Yurniwati \& Hanum [26] concluded that the implementation of Discovery Learning may increase students learning outcomes because it provided new abilities for students such as observing, discussing, concluding, and communicating.

The use of appropriate learning strategies can increase students' motivation in the learning process because it can motivate students to learn. Learning strategies of Problem Solving and Discovery Learning make it easier for the teacher to convey the materials. Besides, the use of these two strategies is expected to make students have optimum learning and fun and can improve learning outcomes better than before.

Based on the description above, one of the reasons for the low student learning outcomes is that the teacher uses an inappropriate learning strategy. The use of the problem-solving strategy is an effort to improve student learning outcomes. If learning motivation increases, it is expected that student learning outcomes improve. This research aims at determining: (1) the impact of Problem Solving Learning and Discovery Learning strategies on student mathematics learning outcomes, (2) the impact of learning motivation on student mathematics learning outcomes, and (3) the interaction of learning strategies and learning motivation on student mathematics learning outcomes.

\section{Hypothesis}

The hypothesis in this study is the associative hypothesis. The associative hypothesis is a temporary answer to the associative problem statement, which states the relationship between two or more variables [28]. Based on the description above, to analyze and examine the Problem Solving and Discovery Learning strategies on learning outcomes analyzed from learning motivation, the hypotheses can be defined as follows: (1) there is an influence of Problem Solving and Discovery Learning strategies about mathematical learning outcomes; (2) there is an influence of learning motivation on mathematics learning outcomes; and (3) there is an interaction between learning strategies and learning motivation towards learning outcomes in mathematics.

\section{Methods}

\subsection{Design of Research}

This work was a quasi-experimental study that consisted of two classes, namely experimental and control classes. The experimental class was given an action of mathematics learning with the Problem-Solving strategy $\left(\mathrm{X}_{1}\right)$ while the control class was given action mathematics learning with the Discovery Learning strategy $\left(\mathrm{X}_{2}\right) \cdot \mathrm{O}_{1}$ was a learning outcome after being given the Problem-Solving strategy, $\mathrm{O}_{2}$ was a learning outcome after being given the Discovery Learning strategy. The research design can be seen in Table 1.

Table 1. Research Design

\begin{tabular}{|c|c|c|}
\hline Class & Treatment & Post-test \\
\hline Experimental & $\mathrm{X}_{1}$ & $\mathrm{O}_{1}$ \\
\hline Control & $\mathrm{X}_{2}$ & $\mathrm{O}_{2}$ \\
\hline
\end{tabular}

\subsection{Population and Sample}

The population of the research was all of the 7th-grade students at one of state secondary schools in Surakarta, Central Java, Indonesia. A total of 57 students from two different classes were involved in the study, as many as 29 students were assigned as the experimental group and another 28 students as the control group. They were selected through cluster random sampling technique. The group assigned as the experimental group was instructed using the problem-solving strategy whereas the other group used discovery learning. The samples, both experimental and control classes were tested before being provided with action to assure that the two classes had the same initial ability.

\subsection{Data Collection}

The techniques of collecting data in this research were documentation, test, and questionnaire. The documentation was used for collecting students learning outcomes on the Odd Semester Assessment. The test was for obtaining data of learning outcomes after being given an action. The questionnaire was for obtaining students learning motivation data. The instruments for collecting data in this research consisted of tests and learning motivation questionnaire.

The test instrument consisted of six essay items and was carried out at the fourth meeting. The questionnaire instrument contained 23 items consisting of 12 positive questions and 11 negative questions. The stages of developing the instrument before being given to students were as follows: (1) making indicators, (2) making grades, (3) arranging the instrument, (4) determining the score, (5) examining the instrument, (6) analyzing the validity and reliability. This research used the formula of Product Moment to examine the instrument validity and formula of 
Cronbach Alpha to examine the instrument reliability. To find out the instrument that fulfills the validity and reliability requirements of the sample class, then the instrument test is conducted on non-sample classes.

Based on the analysis, the results of the instrument validity test of six essay questions were declared valid and used to obtain student learning outcomes data. Then, the validity test of the questionnaire as many as 30 items produced 23 items that were declared valid and were used to obtain student learning motivation data. The calculation of the reliability of the test instrument values obtained 0.6142 and the questionnaire instrument values obtained 0.792 meaning that the instrument had a high-reliability category.

\subsection{Procedures}

Both sample classes were given different learning strategy actions during the three meetings. The experimental class was treated with the Problem-Solving strategy and the control class was treated with the Discovery Learning strategy. At the first meeting, both sample classes were given the material concept of one variable linear equations, at the second meeting they were given the material completion of one variable linear equations with addition or subtraction, and at the third meeting, they were given the material solving one linear variable with multiplication or division. At the fourth meeting, the experimental class and the control class were given the same learning achievement test. Finally, both classes were given questionnaires to get learning motivation data.

In the experimental class, the learning process through Problem Solving began with the teacher delivering the learning objectives and the material benefits and motivating the students to start following the learning process. Next, the teacher did the apperception through question and answer. At the core activity, the teacher presented information about the learning material in person or lecture. Furthermore, the teacher organized the students in study groups by dividing the class heterogeneously, in which each group consisted of 4-5 students and each group was given a student worksheet. Students were asked to solve the problems on a worksheet by connecting the knowledge they already had with the group. The teacher helped the group when they had difficulties in doing the worksheet. In the next stage, the teacher asked the representatives of each group to present the results of their discussion. The teacher added when there were deficiencies in the student work in the presentation. In the closing activity, the teacher guided the students to conclude the material they obtained and then gave a few questions to measure student abilities. These steps were carried out until the third meeting.

In the control class, the Discovery Learning process began with the teacher delivering the learning objectives, conveying the benefits of the material, and motivating students to be enthusiastic about the learning process. Next, the teacher did the apperception through question and answer. At the core activity of the stimulus stage, students were asked to observe the problems presented by the teacher. Then in the stage of identifying the problem, the teacher provided questions or keywords so that students could formulate questions from the problem presented by the teacher. In the data collection phase, the teacher divided the groups heterogeneously with 4-5 students in each group and the teacher gave a worksheet to each group. Students were asked to understand and find ways to solve problems on a worksheet. Furthermore, in the data processing stage, the teacher asked the students to discuss to solve problems on a worksheet. The teacher's role was to help students when they encountered difficulties. In the verification phase, the teacher asked one of the students from the group representative to write the answers on the board and to present the results of the group discussion. In the final stage, the teacher guided the students to conclude the material they learned. Next to the closing phase, the teacher gave several questions to measure student abilities. These steps were carried out until the third meeting.

At the fourth meeting of the experimental and control classes were given the same learning achievement test after the two classes were given the learning strategy treatment. After that, both classes were given a questionnaire to obtain the learning motivation data. This research was more focused on measuring learning outcomes after being given competency and student motivation. In this study, the gender variable was ignored during the learning process [11].

\subsection{Analysis of Data}

The data analysis technique used was the two-way analysis of variance. The normality test was the Lilliefors and the homogeneity test was the Bartlett method. Besides, the double comparison test used was the Scheffe method.

\section{Result}

The balance test in the two sample groups was the t-test to find out that the experimental class and the control class had the same initial ability. Based on the calculation of the $t$-test, the value obtained was $t_{\text {count }}=0.1372<t_{\text {table }}=2.004$. This meant that $\mathrm{t}_{\text {count }}<\mathrm{t}_{\text {table }}$ then $H_{0}$ was accepted, so it was concluded that the experimental class and the control class had the same initial ability.

Furthermore, the prerequisite test analysis was the normality test and homogeneity test of learning outcomes and student motivation. The normality test was the Lilliefors test at a significance level of $5 \%$ which was carried out to determine that the sample was normally distributed. Details of the normality test results were presented in Table 2. It could be seen that from Table 2 the value obtained was $\mathrm{L}_{\max }$ count $<\mathrm{L}_{\text {table. }}$. Thus it was concluded the sample was from normally distributed populations. 
Table 2. The Normality Test Results

\begin{tabular}{|c|c|c|c|c|c|c|}
\hline & Class & $\mathrm{n}$ & $\mathrm{L}_{\text {max count }}$ & $\mathrm{L}_{\text {table }}$ & Decision & Conclusion \\
\hline \multirow{2}{*}{$\begin{array}{c}\text { Learning } \\
\text { Outcomes }\end{array}$} & Experimental & 29 & 0.1222 & 0.165 & $H_{0}$ was accepted & Normal \\
\cline { 2 - 7 } & Control & 28 & 0.1397 & 0.167 & $H_{0}$ was accepted & Normal \\
\hline \multirow{2}{*}{$\begin{array}{c}\text { Learning } \\
\text { Motivation }\end{array}$} & High & 15 & 0.1805 & 0.22 & $H_{0}$ was accepted & Normal \\
\cline { 2 - 7 } & Medium & 22 & 0.134 & 0.189 & $H_{0}$ was accepted & Normal \\
\cline { 2 - 7 } & Low & 20 & 0.1212 & 0.19 & $H_{0}$ was accepted & Normal \\
\hline
\end{tabular}

Table 3. The Summary Analysis of Homogeneity Test

\begin{tabular}{ccccc}
\hline Sources & $x_{\text {count }}^{2}$ & $x_{\text {table }}^{2}$ & Decision & Conclusion \\
\hline Learning Strategies & -1.22518 & 3.841 & $H_{0}$ was accepted & Homogeneous \\
Learning Motivation & 5.3737 & 5.991 & $H_{0}$ was accepted & Homogeneous \\
\hline
\end{tabular}

Table 4. The Summary of Two Way Analysis of Variance

\begin{tabular}{ccccccc}
\hline Sources & SS & df & MS & $\mathrm{F}_{\text {count }}$ & $\mathrm{F}_{\text {table }}$ & Decision \\
\hline Learning Strategies (A) & 438.9208 & 1 & 438.9208 & 4.433 & 4.03 & $H_{0}$ was rejected \\
Learning Motivation (B) & 7806.625 & 2 & 3903.312 & 39.425 & 3.18 & $H_{0}$ was rejected \\
Interaction (AB) & 449.8408 & 2 & 224.9204 & 2.272 & 3.18 & $H_{0}$ was accepted \\
Error (E) & 5049.377 & 51 & 99.00739 & & & \\
Total (T) & 13744.76 & 56 & & & & \\
\hline
\end{tabular}

Table 5. The Marginal average of Mathematics Learning Outcomes

\begin{tabular}{ccccc}
\hline \multirow{2}{*}{ Learning Strategies } & \multicolumn{3}{c}{ Learning Motivation } & \multirow{2}{*}{$\begin{array}{c}\text { Marginal } \\
\text { Average }\end{array}$} \\
\cline { 2 - 4 } & High $\left(\mathrm{B}_{1}\right)$ & Medium $\left(\mathrm{B}_{2}\right)$ & Low $\left(\mathrm{B}_{3}\right)$ & 63.3111 \\
Problem Solving $\left(\mathrm{A}_{1}\right)$ & 74.7 & 71.333 & 43.9 & 57.4949 \\
Discovery Learning $\left(\mathrm{A}_{2}\right)$ & 71.4 & 57.3846 & 43.7 & \\
Marginal Average & 73.05 & 64.359 & 43.8 & \\
\hline
\end{tabular}

Meanwhile, the homogeneity test used was the Bartlett test with a significance level of $5 \%$. Details of the homogeneity test results were presented in Table 3 . It could be seen from Table 3 that the significance level of $5 \%$ obtained results from each group $x_{\text {count }}^{2}<X_{\text {table }}^{2}$. It could be concluded that the variances of both sample classes were homogeneous.

Finally, the hypothesis test was carried out using a two-way analysis of variance with a significance level of $5 \%$. A summary of the results of the analysis was shown in Table 4. It could be seen from Table 4 that the source of the learning strategy and learning motivation are $\mathrm{F}_{\text {count }}>$

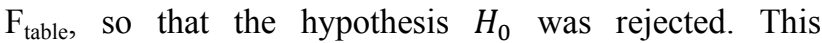
signified that (1) there was an influence of Problem Solving and Discovery Learning strategies on mathematics learning outcomes, (2) there was an influence of learning motivation on mathematics learning outcomes. Meanwhile, the source of the interaction between learning strategies and learning motivation was $\mathrm{F}_{\text {count }}<\mathrm{F}_{\text {table, }}$, which signified that hypothesis $H_{0}$ was accepted. This suggested that (3) there was no interaction between learning strategies and learning motivation towards learning outcomes in mathematics.

Because hypothesis $H_{0}$ was rejected, further testing was needed to determine the average difference in each row and each column using the Scheffe method [4]. The marginal average of learning strategies and learning motivation towards mathematics learning outcomes was presented in Table 5 .

Table 4 showed that there was an influence of Problem Solving and Discovery Learning strategies on mathematics learning outcomes. Because the first hypothesis consisted of two factors, namely the Problem Solving strategy and the Discovery Learning strategy, it was sufficient to compare the marginal average values. Looking at the results in Table 5, the marginal average obtained through the Problem Solving strategy was 63.3111, which was greater than the marginal average of learning outcomes through the Discovery Learning strategy of 57.4949. Therefore, it could be concluded that the Problem Solving strategy was better than the Discovery Learning strategy.

Considering the results presented in Table 4, there was an influence of learning motivation on mathematics learning outcomes. From the last row in Table 5, it could be seen that students who had high learning motivation reached better achievement than those having medium and low learning motivation. Likewise, students with moderate learning motivation had better learning achievement than those having low learning motivation. 


\section{Discussion}

The analyses conducted in this study were a balance test, a validity and reliability test, an analysis prerequisite test (normality test and homogeneity test), and a hypothesis test. In the balance test, the $\mathrm{t}$-test calculation obtained $t_{\text {count }}<$ $\mathrm{t}_{\text {table }}$ signifying that both sample classes had the same initial ability. The tests of validity and reliability aim at ensuring that the instruments compiled produced valid data. Based on calculations, the validity test of the test instruments contained six test essay items, and all items were declared valid with a reliability value of 0.6142 meaning that it had a high category. Meanwhile, the questionnaire instrument validity test contained 30 test items and as many as 23 items were declared valid with a reliability value of 0.792 meaning that it had a high category. Learning outcome data and learning motivation that had been obtained could be used for analyzing prerequisite analysis tests. The

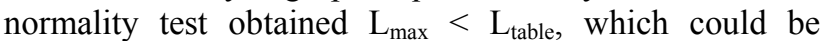
concluded that the sample came from a normally distributed population. Meanwhile, the homogeneity test results obtained from each group $x_{\text {count }}^{2}<\chi_{\text {table }}^{2}$ means that it could be concluded that the variances of the two populations were homogeneous. After that, a two-way analysis of variance test and post-Anava multiple comparison test was conducted. The following discussion was the results of the hypothesis test that had been done.

The first hypothesis test results showed that there was an influence of learning strategies on student learning outcomes. This was supported by Zakaria \& Malek's research [27] which stated that learning strategies had a significant influence on academic performance. On the other hand, Suhendri \& Mardalena's research [22] stated that the Problem Solving strategy could improve student learning outcomes. Similarly, it was also supported by the research of Tambunan [24] concluding that the Problem-Solving strategy was more effective than the Scientific Approach for student abilities in communication, creativity, problem-solving, and mathematical reasoning. TIt was in line with the research of Sappaile \& Djam'an [16] concluding that the results of teaching and learning mathematics using the Problem-Solving method were better than the lecture method. Meanwhile, the research of Murdiana [9] stated that Problem-Solving could increase learning motivation.

Besides, the research of Yurniwati \& Hanum [26] concluded that the Discovery Learning strategy may improve students learning outcomes as it provided the students with many new abilities. Herdiana et al. [5] concluded that student's ability to solve problems with the Discovery Learning strategy was categorized medium with $80 \%$ level of mastery of the materials and this strategy was effective to improve student's ability to solve the problem. The research of Simamora, Saragih, \& Hasratuddin [18] concluded that there was an increase in the student mathematical problem-solving skills and self-efficacy after being provided with a guide of the Discovery Learning strategy.

The first hypothesis consisted of two factors, namely the
Problem-Solving Strategy and Discovery Learning Strategy. Based on Table 5, the marginal average of learning outcomes obtained through Problem Solving Strategy was 63.3111, which was greater than learning outcomes through the Discovery Learning Strategy reaching 57.4949. Thus, it could be concluded that the Problem-Solving strategy was better than the Discovery Learning strategy. This was supported by the research of Bey \& Asriani [3] concluding that there was an increase of activities and learning outcomes in students of one of the state secondary schools at Kalisusu, Buton, Indonesia using the Problem-Solving approach on the topic of linear equation system with two variables.

Learning using Problem Solving strategy produced better learning outcomes than using the Discovery Learning strategy. This was because the Problem-Solving strategy was centered on providing problems so that it could stimulate the students thinking abilities in solving problems. Also, the Problem-Solving strategy made the students active in following the learning process, so that they must think scientifically and develop a deep understanding of a problem by thinking using relevant ideas. Otherwise, in Discovery Learning there were habits and cultural factors that required independence and habit of acting as a subject so that these requirements make students forced to participate in learning activities [6]. As a result, learning through the Problem Solving strategy was better and more effective in improving student learning outcomes.

The second hypothesis test pointed out that is student learning motivation influenced mathematics learning outcomes. This was in line with the research of Taurina [25] concluding that motivation influenced learning outcomes. On the other hand, the research of Akpan \& Umobong [1] concluded that motivation to learn greatly influenced academics.

In the second hypothesis, student motivation was divided into three categories, namely high, medium, and low. It could be seen from Table 5 as follows. Firstly, students who had high learning motivation may have greater learning outcomes, than those having moderate learning motivation. It could be seen as the average obtained from high category learning motivation 73.05 that was greater than the average obtained from the medium category learning motivation 64.359. Secondly, the learning outcome of the students who had high learning motivation have better than those having low learning motivation. It was evident that the average obtained from high category learning motivation 73.05 was greater than the average low category learning motivation 43.8. Thirdly, Students having moderate learning motivation were better than those having low learning motivation. It could be seen that the marginal average obtained from the medium category learning motivation that reached 64.359 was greater than the low category learning motivation by 43.8 . Figure 1 explained the average student learning outcomes from the level of learning motivation. 


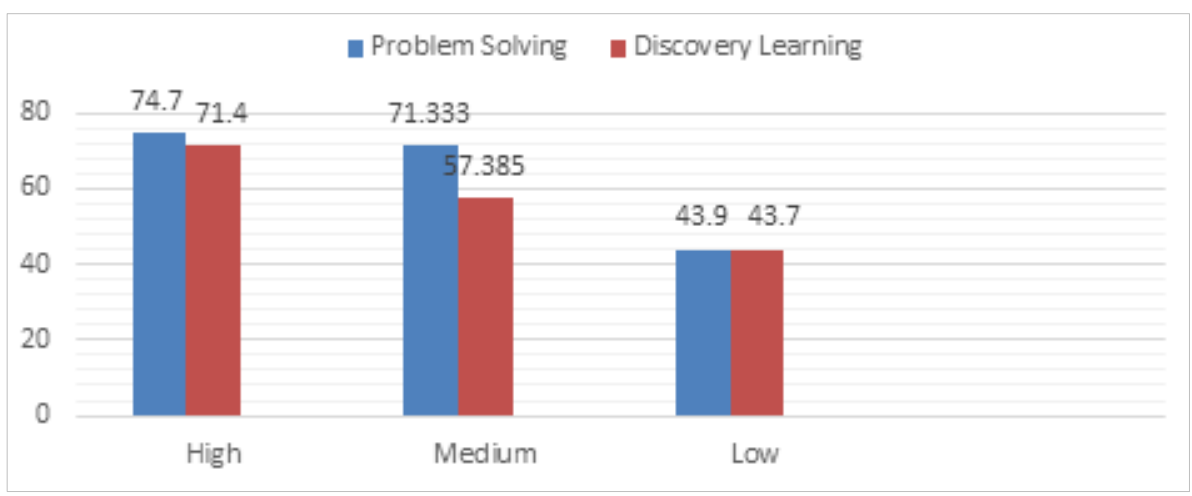

Figure 1. The Average of Student Learning Outcomes in Learning Motivation

The results of the third hypothesis test indicated that there was no interaction between learning strategies and learning motivation towards mathematics learning outcomes. This was in line with the research of Siswati et al. [19] concluding that there was not any interaction between learning strategies and learning motivation on student learning outcomes. An illustration of the lack of interaction between learning strategies and learning motivation towards learning outcomes was presented in Figure 2.

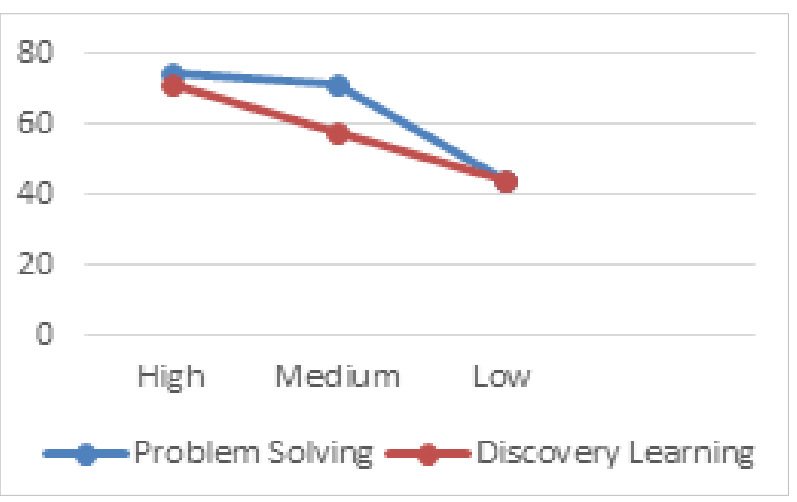

Figure 2. Profile Effect of Variable of Learning Strategies and Learning Motivation

From Figure 2, it could be seen that the average learning outcomes based on learning motivation in the experimental class and the control class were close to each other but did not intersect. It demonstrated that there was not any interaction between learning strategies and learning motivation on student learning outcomes. Average of learning outcomes with the Problem-Solving strategy have better than average of learning outcomes using the Discovery Learning strategy. Also, Figure 2 showed that students with high learning motivation had better learning outcomes than those with moderate and low learning motivation.

\section{Conclusions}

Based on the previous results and discussion, it can be concluded as follows: (1) there is an influence of Problem
Solving and Discovery Learning strategies on mathematics learning outcomes. The marginal average of learning outcome through Problem Solving strategy is greater than the marginal average of learning outcome through Discovery Learning. Thus, it can be concluded that the Problem-Solving learning strategy is better than the Discovery Learning strategy. (2) There is an influence of student learning motivation on learning outcomes in mathematics. Students having high learning motivation have better mathematics learning outcomes than students who have moderate and low learning motivation. It is concluded that learning motivation has an impact on learning outcomes. (3) There is no interaction between learning strategies and learning motivation towards mathematics learning outcomes. Thus, there is not any interaction between Problem Solving strategy and Discovery Learning strategy towards mathematics learning outcomes viewed from student learning motivation.

\section{REFERENCES}

[1] Akpan, I. D., \& Umobong, M. E. (2013). Analysis of Achievement Motivation and Academic Engagement of Students in the Nigerian Classroom. Academic Journal of Interdisciplinary Studies, 2(3), 385-390.

[2] Arseven, A. (2015). Mathematical Modelling Approach In Mathematics Education. Universal Journal of Educational Research, 3(12), 973-980.

[3] Bey, A., \& Asriani. (2013). Penerapan Pembelajaran Problem Solving untuk Meningkatkan Aktivitas dan Hasil Belajar Matematika pada Materi SPLDV. Jurnal Pendidikan Matematika, 4(2), 224-239.

[4] Budiyono. (2013). Statistika untuk Penelitian. Surakarta: UNS PRESS.

[5] Herdiana, Y., Wahyudin, \& Sispiyati, R. (2017). Effectiveness of Discovery Learning Model on Mathematical Problem Solving. The 4th International Conference on Research, Implementation, and Education of Mathematics and Science (4th ICRIEMS): Research and 
Education for Developing Scientific Attitude in Sciences And Mathematics. 1868, pp. 1-8. American Institute of Physics Conference Proceedings.

[6] Ilahi, M. T. (2012). Pembelajaran Discovery Strategy dan Mental Vocational Skill. Yogyakarta: Diva Press.

[7] In'am, A., \& Hajar, S. (2017). Learning Geometry through Discovery Learning Using a Scientific Approach. International Journal of Instruction, 10(1), 55-70.

[8] Martaida, T., Bukit, N., \& Ginting, E. M. (2017). The Effect of Discovery Learning Model on Student's Critical Thinking and Cognitive Ability in Junior High School. IOSR Journal of Research \& Method in Education (IOSR-JRME), 7(6), $1-8$.

[9] Murdiana, I. N. (2017). Pembelajaran Pemecahan Masalah Dalam Pembelajaran Matematika. Aksioma: Jurnal Pendidikan Matematika, 4(1), 1-11.

[10] Murtiyasa, B. (2015). Tantangan Pembelajaran Matematika. Prosiding Seminar Nasional Matematika dan Pendidikan Matematika UMS 2015 (pp. 28-47). Universitas Muhammadiyah Surakarta.

[11] Murtiyasa, B., \& Hapsari, S. N. (2020). The Effect of TAI and STAD Strategy towards Learning Outcomes Reviewed from Mathematical Communication Skills. Universal Journal of Educational Research, 8(6), 2406-2415.

[12] Murtiyasa, B., Rejeki, S., \& Merdekawati, A. (2019). Students' Thinking in Solving Geometric Problems Based on PISA Levels. Journal of Physics: Conferences Series, 1320(1), 6-12.

[13] OECD. (2019). PISA 2018 Results (Volume I): What Students Know and Can Do, PISA: Vol. I. OECD Publishing.

[14] Prasetya, Kartono, A., \& Widodo, A. T. (2012). Model IDEAL Problem Solving Untuk Pencapaian Kemampuan Pemecahan Masalah di Kelas Olimpiade. Jurnal Lembaran Ilmu Kependidikan, 41(1), 1-6.

[15] Purwanto. (2011). Evaluasi Hasil Belajar. Surakarta: Pustaka Belajar.

[16] Sappaile, B. I., \& Djam'an, N. (2017). The Influence of Problem-Solving Methods on Students' Mathematics Learning Outcomes. Global Journal of Engineering Education, 19(3), 267-272.

[17] Sardiman, A. M. (2012). Interaksi dan Motivasi Belajar-Mengajar. Jakarta: PT RajaGrafindo Persada.

[18] Simamora, R. E., Saragih, S., \& Siregar, H. (2019).
Improving Students' Mathematical Problem Solving Ability and Self-Efficacy through Guided Discovery Learning in Local Culture Context. International Electronic Journal of Mathematics Education, 14(1), 61-72.

[19] Siswati, Ekohariadi, \& Sondang, M. (2014). Pengaruh Model Pembelajaran dan Motivasi Berprestasi Terhadap Hasil Belajar Siswa Pada Materi MS Excel. Jurnal Pendidikan Vokasi: Teori dan Praktek, 2(1), 36-40.

[20] Siswono, T. Y., Hartono, S., Kohar, A. W., Karim, \& Kurniawan. (2019). Instrumentalist Teachers' Beliefs in Practicing Mathematical Problem Solving. Universal Journal of Educational Research, 7(12), 2851-2856.

[21] Suastika, K. (2017). Mathematics Learning Model of Open Problem Solving to Develop Students' Creativity. International Electronic Journal of Mathematics Education, 12(3), 569-577.

[22] Suhendri, H., \& Mardalena, T. (2013). Pengaruh Metode Pembelajaran Problem Solving Terhadap Hasil Belajar Matematika Ditinjau Dari Kemandirian Belajar. Jurnal Formatif, 3(2), 105-114.

[23] Syah, M. (2014). Psikologi Pendidikan dengan Pendekatan Baru. Bandung: PT Remaja Rosdakarya.

[24] Tambunan, H. (2019). The Effectiveness of the Problem Solving Strategy and the Scientific Approach to Students' Mathematical Capabilities in High Order Thinking Skills. International Electronic Journal of Mathematics Education, 14(2), 292-302.

[25] Taurina, Z. (2015). Students' Motivation and Learning Outcomes: Significant Factors in Internal Study Quality Assurance System. International Journal for Cross-Disciplinary Subjects in Education (IJCDSE), 5(4), 2625-2630.

[26] Yurniwati, \& Hanum, L. (2017). Improving Mathematics Achievement of Indonesian 5th Grade Students through Guided Discovery Learning. Journal on Mathematics Education, 8(1), 77-84.

[27] Zakaria, M., \& Malek, N. A. (2019). Effect of Learning and Teaching Preference Approaches on Academic Performance among Malaysian Accounting Students. Universal Journal of Educational Research, 7(11), 2384-2396.

[28] Zarkasyi, W. (2018). Penelitian Pendidikan Matematika. Bandung: PT Rafika Aditama.

[29] Zulyadaini. (2017). Effects of Creative Problem Solving Learning Model on Mathematical Problem Solving Skills of Senior High School Students. IOSR Journal of Research \& Method in Education (IOSR-JRME), 7(3), 33-37. 